\title{
KEPUTUSAN PETANI DALAM MEMASARKAN BAHAN OLAH KARET DI DESA PONDOK MEJA KECAMATAN MESTONG KABUPATEN MUARO JAMBI
}

\author{
Urip $^{1)}$, Saad Murdy ${ }^{2)}$ dan Adlaida Malik ${ }^{2)}$ \\ 1) Alumni Program Studi Agribisnis Fakultas Pertanian Universitas Jambi \\ 2) Staf Pengajar Program Studi Agribisnis Fakultas Pertanian Universitas Jambi \\ Email: Mangurip91@gmail.com
}

\begin{abstract}
ABSTRAK
Penelitian ini dilakukan dengan tujuan untuk mengetahui faktor-faktor yang mempengaruhi keputusan petani dalam memasarkan bahan olah karet di Desa Pondok Meja Kecamatan Mestong Kabupaten Muaro Jambi. Keputusan dalam penelitian ini adalah pilihan yang dijatuhkan oleh petani pada lembaga pemasaran yaitu koperasi/kelompok tani atau pedagang pengumpul desa yang akan digunakannya untuk memasarkan bahan olah karet miliknya. Metode pengambilan sampel menggunakan metode proportional random sampling dengan jumlah responden sebanyak 60 orang dengan alokasi 32 orang yang memasarkan ke koperasi/kelompok tani dan 28 orang yang memasarkan ke pedagang pengumpul desa. Analisis data menggunakan metode pendekatan analisis regresi binary logistic. Faktor-faktor yang diduga mempengaruhi keputusan memasarkan bahan olah karet dalam penelitian ini antara lain pendidikan, pengalaman, jumlah tanggungan, tabungan dan produksi. Hasil penelitian menunjukkan bahwa terdapat 3 faktor yang berpengaruh secara signifikan dalam pengambilan keputusan memasarkan bahan olah karet di Desa Pondok Meja Kecamatan Mestong Kabupaten Muaro Jambi. Faktor-faktor yang dimaksud antara lain jumlah tanggungan, tabungan dan produksi . Keputusan petani dalam memilih lembaga pemasaran bahan olah karet di Desa Pondok Meja juga didukung oleh faktor kemudahan dalam proses pemasaran. Hal ini membuktikan bahwa faktor pendidikan dan pengalaman tidak berpengaruh terhadap keputusan petani dalam memasarkan bahan olah karet di Desa Pondok Meja Kecamatan Mestong Kabupaten Muaro Jambi.
\end{abstract}

Kata Kunci : Keputusan, Pemasaran, Bahan Olah Karet

\section{ABSTRACT}

This research was conducted to determine the factors that influence the decisions of farmers in the market if the rubber material in the Pondok Meja Village in Subdistrict Mestong in District Muaro Jambi. Decisions in this research is the choice imposed by the farmer on the cooperative marketing agencies / groups of farmers or traders village that will be used to market though his rubber material. The sampling method using proportional random sampling method with the number of respondents as many as 60 people with 32 people who market their allocation to cooperatives / farmer groups and 28 people who market traders to the village. Data analysis using binary logistic regression analysis approach. Factors thought to influence marketing decisions if the rubber material in this study include education, experience, number of dependents, savings and production. The results showed that there are three factors that affect significantly the marketing decisionmaking if the rubber material in the Pondok Meja Village in Subdistrict Mestong in District Muaro Jambi. The factors mentioned include the number of members, savings and production. Farmers' decision in choosing marketing agencies if the rubber material in the Village cottage table is also supported by the ease factor in the marketing process. This proves that the education and experience factors do not affect the decisions of farmers in marketing if the rubber material in the Pondok Meja Village in Subdistrict Mestong in District Muaro Jambi.

Keyword : Decision, Marketing, Material Rubber 


\section{PENDAHULUAN}

Sektor pertanian mencakup sub sektor tanaman bahan makanan (tabama), tanaman perkebunan, peternakan dan hasil-hasilnya, kehutanan dan sub sektor perikanan. Pada tahun $2009-$ 2013 kontribusi sektor ini terhadap PDRB paling dominan dan menjadi tumpuan penyerapan tenaga kerja. Pada kurun waktu lima tahun terakhir, sub sektor tanaman perkebunan mendominasi sektor pertanian. Kontribusinya sejak tahun 2009 hingga tahun 2013 berkisar antara 13,35 persen hingga 16,40 persen lebih tinggi dari sub sektor tanaman bahan makanan yang peranannya antara 8,46 hingga 8,98 persen (BPS Provinsi Jambi, 2013).

Provinsi Jambi merupakan penghasil karet utama nasional disamping provinsi lainnya yang tersebar di beberapa kabupaten. Hampir seluruh kabupaten memiliki perkebunan karet rakyat. Usahatani karet di Provinsi Jambi selama lima tahun (2009 - 2013) setiap tahunnya mengalami peningkatan baik produksi maupun produktivitasnya. Pada tahun 2009 produksi karet di Provinsi Jambi mencapai 280.620 ton dengan produktivitas sebesar $823 \mathrm{~kg} / \mathrm{ha}$ dan pada tahun 2013 produksi karet meningkat menjadi 323.271 ton dengan produktivitas mencapai $922 \mathrm{~kg} / \mathrm{ha}$ (Disbun Provinsi Jambi, 2013). Mestong merupakan kecamatan dalam Kabupaten Muaro Jambi yang memiliki luas areal perkebunan karet terluas kedua yakni sebesar 14.597 ha setelah Kecamatan Sekernan dan produksi sebesar 6.880 ton. Desa di Kecamatan Mestong yang memiliki luas areal perkebunan karet terluas adalah Desa Pondok Meja. Desa ini memiliki luas areal perkebunan karet sebesar 1.657 ha dan dengan produksi mencapai 259,35 ton (Disbun Provinsi Jambi, 2013).

Pemasaran bahan olah karet dari petani ke pabrik crumb rubber dilakukan melalui dua saluran pemasaran yaitu lembaga pemasaran formal (lelang) dan lembaga pemasaran non formal (non lelang). Pada umumnya, pemasaran bahan olah karet di Desa Pondok Meja dilakukan melalui lembaga pemasaran non formal yaitu pedagang pengumpul desa (tengkulak) dan koperasi/kelompok tani. Pedagang pengumpul atau tengkulak merupakan individu pedagang yang melakukan kegiatan pemasaran dalam pembelian bokar petani kemudian menjualnya kembali ke pedagang lain. Lembaga pemasaran kedua yaitu lembaga yang sengaja dibentuk oleh petani melalui kelompok tani dan koperasi.

Pemasaran bahan olah karet pada koperasi/kelompok tani lebih unggul dibandingkan pada pedagang pengumpul desa, beberapa diantaranya mengenai harga dan proses pemasaran. Harga bokar di koperasi/kelompok tani relatif lebih tinggi dibandingkan pada pengumpul. Pada bulan Januari 2015 harga bokar di tingkat koperasi sebesar Rp 7.850,-, kelompok tani sebesar Rp 7.500,sedangkan pada pedagang pengumpul sebesar Rp 5.500,-. Walaupun harga bokar di koperasi/kelompok tani relatif lebih tinggi, akan tetapi petani hanya bisa memasarkan bokar ke koperasi/kelompok tani pada waktu yang ditentukan yakni setiap dua minggu sekali, sedangkan waktu pemasaran bokar pada pedagang pengumpul bisa kapan saja. Mengenai lokasi pemasaran, pedagang pengumpul bersedia untuk menjemputnya ke rumah petani. sedangkan di koperasi/kelompok tani, petani membawa sendiri bokarnya ke tempat pemasaran yang telah ditentukan.

Berdasarkan uraian di atas maka penulis meneliti tentang "Keputusan Petani Dalam Memasarkan Bahan Olah Karet di Desa Pondok Meja Kecamatan Mestong Kabupaten Muaro Jambi". Penelitian ini dilakukan dengan tujuan untuk mengetahui faktor-faktor yang mempengaruhi keputusan petani dalam memasarkan bahan olah karet di Desa Pondok Meja Kecamatan Mestong Kabupaten Muaro Jambi. 


\section{METODE PENELITIAN}

Ruang lingkup penelitian difokuskan untuk mengetahui faktor-faktor yang mempengaruhii keputusan petani dalam memasarkan bahan olah karet. Selanjutnya dipilih wilayah Desa Pondok Meja dalam penelitian ini dengan pertimbangan bahwa lokasi tersebut Meja sebagian besar penduduknya bermata pencaharian sebagai petani karet serta memiliki lembaga pemasaran bahan olah karet yang cukup beragam yaitu koperasi, kelompok tani dan pedagang pengumpul desa (tengkulak). Penelitian dilaksanakan dari tanggal 3 Juni 2015 sampai 3 Juli 2015.

Data yang digunakan merupakan data primer yang diperoleh dari petani responden yang melakukan kegiatan usahatani karet serta memasarkan ke lembaga pemasaran (koperasi/kelompok tani atau pedagang pengumpul desa. Data sekunder diperoleh dari instansi terkait seperti Badan Pusat Statistik Provinsi Jambi, Dinas Perkebunan Provinsi Jambi, Dinas Perkebunan dan Kehutanan Kabupaten Muaro Jambi, Kantor Desa Pondok Meja, Koperasi Usaha Jaya dan hasil-hasil penelitian terdahulu. Jumlah sampel yang diambil dalam penelitian ini adalah $15 \%$ dari populasi petani karet sehingga didapat 60 responden.

Analisis yang digunakan dalam penelitian ini menggunakan analisis kuantitatif yang dideskriptifkan. Pengumpulan data primer dilakukan dengan pengisian kuesioner dari petani responden. Selain itu juga dilakukan pengumpulan data sekunder melalui penelusuran internet dan dinas terkait dalam penelitian ini. Analisis kuantitatif yang digunakan untuk mengetahui faktor-faktor yang mempengaruhi keputusan petani dalam memasarkan bahan olah karet ke lembaga pemasaran (koperasi/kelompok tani atau pedagang pengumpul desa) menggunakan analisis regresi logistik biner. Regresi logistik disebut model regresi respon dikotomis dengan variabel dependen (keputusan) bernilai 0 dan 1 dimana dalam penelitian ini :

$Y=1 ;$ apabila petani memasarkan bokar ke koperasi/kelompok tani

$\mathrm{Y}=0$; apabila petani memasarkan bokar ke pedagang pengumpul desa

Persamaan model logit pada penelitian ini adalah :

$$
\mathrm{Yi}=\operatorname{Ln}\left(\frac{P i}{1-P i}\right)=\beta_{0}+\beta_{1} X_{1}+\beta_{2} X_{2}+\beta_{3} X_{3}+\beta_{4} X_{4}+\beta_{5} X_{5}
$$

Keterangan :

$Y i=$ Probabilitas Keputusan petani

1 : jika petani memasarkan bokar ke koperasi/kelompok tani;

$0=$ jika petani memasarkan bokar ke pedagang pengumpul.

$X_{1}=$ Pendidikan petani (tahun)

$X_{2}=$ Pengalaman petani (tahun)

$X_{3}=$ Jumlah tanggungan (orang)

$X_{4}=$ Tabungan (rupiah)

$X_{5}=$ Produksi dinyatakan $(\mathrm{kg})$

$\beta_{1}-\beta_{5}=$ Koefisien Regresi

\section{Uji Ekonometrika}

Uji multikolinearitas digunakan untuk mengetahui ada tidaknya hubungan linear antar variabel independen dalam model regresi. Prasyarat yang harus dipenuhi dalam model regresi adalah tidak adanya multikolinearitas. Adanya multikolinearitas diantara variabel-variabel independen secara statistic tidak signifikan, mengakibatkan tidak diketahui adanya variabel independen yang 
mempengaruhi variabel independen. Menurut Ghozali (2001), jika antar variabel bebas memiliki korelasi yang cukup tinggi (diatas 0,90 ) maka hal ini merupakan indikasi adanya multikolinearitas.

Heteroskedastisitas berarti bahwa variansi error bersifat tidak konstan/tidak identik (Setiawan, 2010). Masalah heteroskedastisitas sering dijumpai dalam data cross section dibanding data time series. Heteroskedastisitas dapat dideteksi menggunakan beberapa pengujian statistika yaitu uji korelasi Rank-Spearman, uji Park dan uji Goldfeld-Quandt. Kasus heteroskedastisitas dalam model dapat diatasi dengan beberapa cara yaitu transformasi variabel baik variabel respon, variabel penjelas maupun keduanya serta dengan metode kuadrat terkecil tertimbang.

\section{Uji Statistik}

Koefisien determinasi pada regresi binary logistic dapat dilihat dari nilai $\mathrm{R}^{2}$ dan adjusted $\mathrm{R}^{2}$ Penggunaan adjusted $R^{2}$ sebagai acuan untuk melihat nilai koefisien determinasi berlaku untuk regresi dengan lebih dari dua variabel bebas (Gujarati, 2006). Nilai $R^{2}$ pada output SPSS disebut Pseudo- $R^{2}$ karena dihitung berbeda dengan penghitungan $R^{2}$ pada analisis regresi berganda atau analisis regresi sederhana. Pada regresi binary logistic nilai $R^{2}$ dilihat dari nilai Nagelkerke $R$ Square yang ada didalam output SPSS. Nilai $R^{2}$ memiliki rentang nilai antara 0 sampai 1 . Jika nilai $R^{2}$ sama dengan 0 , maka tidak ada sedikitpun presentase sumbangan pengaruh yang diberikan variabell independen terhadap variabel dependen, atau variasi variabel independen yang digunakan dalam model tidak menjelaskan sedikitpun variasi variabel dependen.

Pengujian model dilakukan untuk mengetahui pengaruh variabel independen terhadap variabel dependen secara bersama-sama (overall) didalam model. Uji signifikansi model menggunakan Uji Hosmer and Lemeshow dengan hipotesis sebagai berikut :

$\mathrm{H}_{0}$ : $\quad$ Model telah cukup mampu menjelaskan data (sesuai)

$\mathrm{H}_{1}$ : Model tidak cukup mampu menjelaskan data

Kriteria penolakan $\mathrm{H}_{0}$ terjadi jika nilai Hosmer and Lemeshow Test sama dengan atau kurang dari 0,05 . Hal ini berarti terdapat perbedaan yang signifikan antara klasifikasi yang diprediksi dengan klasifikasi yang diamati sehingga Goodness of Fit model tidak baik karena model tidak dapat memprediksi nilai observasinya.

Uji signifikansi parameter dilakukan untuk mengetahui pengaruh masing-masing variabelvariabel independen terhadap variabel dependen sehingga diketahui variabel independen yang signifikan mempengaruhi variabel dependen. Pengujian keberartian parameter (koefisien $\beta$ ) ini secara partial dapat dilakukan melalui Uji Wald dengan uji statistik yang dihitung dengan menggunakan nilai statistika berdasarkan distribusi normal Z, bentuk persamaanya sebagai berikut :

$$
Z=\left[\frac{\beta}{\operatorname{Se}(\beta)}\right]
$$

Keterangan :

$\beta \quad: \quad$ Koefisien estimasi model

Se : Standar error 
Kriteria hipotesisnya adalah sebagai berikut :

$\mathrm{H}_{0}: \beta_{i}=0 \quad$ (Variabel independen ke i tidak berpengaruh signifikan terhadap variabel dependen)

$\mathrm{H}_{1}: \beta_{i} \neq 0 \quad$ (Variabel independen ke i berpengaruh signifikan terhadap variabel dependen)

Pengambilan keputusan hipotesis juga dapat dilihat dengan melihat nilai probabilitasnya ( $p$ value). Gujarati (2006) menyatakan bahwa jika nilai p-value lebih kecil dari nilai alpha $(\alpha)$ maka dengan tingkat keyakinan $(1-\alpha)$ hipotesis Ho ditolak. Nilai odds ratio digunakan untuk menginterpretasikan hubungan antara variabel independen dengan variabel dependen yang memiliki perbedaan dengan regresi linear berganda dengan variabel tidak bebas yang berbentuk data kontinyu.

Pada regresi binary logistic, koefisien dari modelnya tidak bisa serta merta diinterpretasikan langsung atau nilai dari koefisien disini tidak mempunyai arti praktis yang layak (Gujarati, 2006). Sejalan dengan itu, pemahaman terhadap arti dari koefisien tidak semudah dalam memahami regresi linear biasa. Oleh karena itu digunakan odds ratio (rasio peluang) sebagai rasio perubahan odds suatu kejadian untuk interpretasi model pada regresi binary logistic (Trihendardi, 2007).

\section{HASIL DAN PEMBAHASAN}

\section{Identitas Responden}

Tingkat pendidikan seseorang akan mempengaruhi kebijakan dalam mengambil suatu keputusan pada kegiatan usahatani. Pendidikan merupakan aktivitas dan usaha manusia untuk meningkatkan kepribadiannya dengan jalan membina potensi-potensi pribadinya yaitu daya pikir, karsa, rasa, cipta dan budi nurani (Ihsan Fuad, 2005). Pendidikan yang dimaksud dalam penelitian ini adalah pendidikan formal yang pernah diikuti oleh petani responden. Petani di daerah penelitian banyak yang telah menempuh pendidikan SD/sederajat sebanyak 45 persen dan 31.7 persen diantaranya memasarkan bokar ke pedagang pengumpul desa. Distribusi petani responden berdasarkan tingkat pendidikan lebih jelasnya dapat dilihat pada Tabel 1.

Tabel 1. Distribusi Petani Responden Berdasarkan Tingkat Pendidikan Formal di Daerah Penelitian Tahun 2015

\begin{tabular}{lcccc}
\hline \multirow{2}{*}{ Tingkat Pendidikan } & \multicolumn{2}{c}{$\begin{array}{c}\text { Memasarkan ke } \\
\text { Koperasi/Kelompok Tani }\end{array}$} & \multicolumn{2}{c}{$\begin{array}{c}\text { Memasarkan ke } \\
\text { Pedagang Pengumpul Desa }\end{array}$} \\
\cline { 2 - 5 } & $\begin{array}{c}\text { Frekuensi } \\
\text { (Orang) }\end{array}$ & Persentase (\%) & Frekuensi (Orang) & Persentase (\%) \\
\hline Tidak Tamat SD & 5 & 8.3 & 4 & 6.7 \\
SD/ Sederajat & 8 & 13.3 & 19 & 31.7 \\
SLTP/ Sederajat & 8 & 13.3 & 6 & 10 \\
SMA/ Sederajat & 5 & 8.3 & 3 & 5 \\
Perguruan Tinggi & 2 & 3.3 & 0 & 0 \\
Jumlah & 28 & 46.5 & 32 & 53.5 \\
\hline
\end{tabular}

Umur petani adalah salah satu faktor yang berkaitan erat dengan kemampuan kerja dalam melaksanakan kegiatan usahatani, umur dapat dijadikan sebagai tolak ukur dalam melihat aktivitas seseorang dalam bekerja bilamana dengan kondisi umuryang masih produktif maka kemungkinan besar seseorang dapat bekerja dengan baik dan maksimal (Hasyim, 2003). Umur yang dimaksud dalam penelitian ini adalah usia yang dihitung mulai saat petani dilahirkan sampai penelitian dilakukan. Petani sebanyak 46,7 persen berumur diatas 50 tahun. Hal ini menggambarkan bahwa 
usahatani karet di daerah penelitian dilaksanakan oleh petani dengan usia yang kurang produktif. Lebih jelasnya dapat dilihat pada Tabel 2.

Tabel 2. Distribusi Petani Responden Berdasarkan Kelompok Umur di Daerah Penelitian Tahun 2015

\begin{tabular}{|c|c|c|c|c|}
\hline \multirow{2}{*}{ Kelompok Umur } & \multicolumn{2}{|c|}{$\begin{array}{c}\text { Memasarkan ke } \\
\text { Koperasi/Kelompok Tani }\end{array}$} & \multicolumn{2}{|c|}{$\begin{array}{c}\text { Memasarkan ke } \\
\text { Pedagang Pengumpul Desa }\end{array}$} \\
\hline & $\begin{array}{l}\text { Frekuensi } \\
\text { (Orang) }\end{array}$ & Persentase (\%) & Frekuensi (Orang) & Persentase (\%) \\
\hline $30-39$ & 6 & 10 & 5 & 8.3 \\
\hline $40-49$ & 10 & 16.7 & 8 & 13.3 \\
\hline $50-59$ & 5 & 8.3 & 14 & 23.3 \\
\hline $60-69$ & 4 & 6.7 & 5 & 8.3 \\
\hline$\geq 70$ & 3 & 5 & 0 & 0 \\
\hline Jumlah & 28 & 46.7 & 32 & 53.3 \\
\hline
\end{tabular}

Pengalaman merupakan salah satu faktor yang mempengaruhi petani dalam menerima suatu inovasi. Pengalaman berusahatani terjadi karena pengaruh waktu yang telah dialami oleh petani. Petani yang berpengalaman dalam menghadapi hambatan-hambatan usahataninya akan tahu cara mengatasinya. Semakin banyak pengalaman petani maka diharapkan produktifitas petani akan semakin tinggi, sehingga dalam mengusahakan usahataninya akan semakin baik dan sebaliknya jika petani tersebut belum atau kurang berpengalaman akan memperoleh hasil yang kurang memuaskan (Hasan, 2002). Pengalaman yang dimaksud dalam penelitian ini adalah lamanya kegiatan usahatani yang telah dialami oleh petani responden khususnya dalam hal pemasaran bokar. Petani di daerah penelitian sebanyak 43,4 persen telah berpengalaman berusahatani karet selama 20 - 29 tahun . Frekuensi petani responden yang memasarkan bokarnya ke koperasi/kelompok tani maupun ke pedagang pengumpul desa sama-sama berjumlah 13 orang. Hal ini menunjukkan bahwa berdasarkan pengalaman petani, baik koperasi/kelompok tani maupun pedagang pengumpul desa memiliki penilaian yang sama dalam pengambilan keputusan petani untuk memasarkan bokarnya. Lebih jelas mengenai pengalaman berusahatani dapat dilihat pada Tabel 3 .

Tabel 3. Distribusi Petani Responden Berdasarkan Pengalaman di Daerah Penelitian Tahun 2015

\begin{tabular}{ccccc}
\hline \multirow{2}{*}{$\begin{array}{c}\text { Pengalaman } \\
\text { Berusahatani (Tahun) }\end{array}$} & \multicolumn{2}{c}{$\begin{array}{c}\text { Memasarkan ke } \\
\text { Koperasi/Kelompok Tani }\end{array}$} & \multicolumn{2}{c}{$\begin{array}{c}\text { Memasarkan ke } \\
\text { Pedagang Pengumpul Desa }\end{array}$} \\
\cline { 2 - 5 } & $\begin{array}{c}\text { Frekuensi } \\
\text { (Orang) }\end{array}$ & Persentase (\%) & Frekuensi (Orang) & Persentase (\%) \\
\hline $10-19$ & 6 & 10 & 2 & 3.3 \\
$20-29$ & 13 & 21.7 & 13 & 21.7 \\
$30-39$ & 2 & 3.3 & 12 & 20 \\
$40-49$ & 5 & 8.3 & 2 & 3.3 \\
$50-59$ & 0 & 0 & 3 & 5 \\
$\geq 60$ & 2 & 3.3 & 0 & 0 \\
Jumlah & 28 & 46.6 & 32 & 53.4 \\
\hline
\end{tabular}

Luas lahan merupakan salah satu faktor produksi yang sangat penting dalam menunjang sebuah usahatani. Tanah sangat berpengaruh terhadap pertumbuhan dan perkembangan tanaman. Pada usahatani karet lahan sangat dibutuhkan karena lahan merupakan suatu media atau tempat yang dibutuhkan untuk melakukan usahatani karet. Semakin luas lahan yang diusahakan maka akan semakin tinggi tingkat produksi dan pendapatan perkesatuan luasnya (Suratiah, 2006). Luas penguasaan lahan pertanian merupakan sesuatu yang sangat penting dalam proses produksi ataupun 
usahatani. Semakin sempit luas lahan yang dimiliki akan mengakibatkan ketidakefisienan usahatani kecuali jika usahatani dilakukan dengan tertib. Luas lahan yang dimilki berhubungan dengan efisiensi usahatani. Luas lahan yang dimaksud dalam penelitian ini adalah luas lahan yang dimiliki dan dikelola oleh petani responden sendiri. Sebagian besar petani responden di daerah penelitian memiliki luas lahan 1,5 sampai 2 ha dengan persentase 43,4 persen. Lebih jelasnya mengenai luas lahan petani responden dapat dilihat pada Tabel 4.

Tabel 4. Distribusi Petani Responden Berdasarkan Luas Lahan di Daerah Penelitian Tahun 2015

\begin{tabular}{|c|c|c|c|c|}
\hline \multirow{2}{*}{ Luas Lahan (Hektar) } & \multicolumn{2}{|c|}{$\begin{array}{c}\text { Memasarkan ke } \\
\text { Koperasi/Kelompok Tani }\end{array}$} & \multicolumn{2}{|c|}{$\begin{array}{c}\text { Memasarkan ke } \\
\text { Pedagang Pengumpul Desa }\end{array}$} \\
\hline & $\begin{array}{l}\text { Frekuensi } \\
\text { (Orang) }\end{array}$ & Persentase (\%) & Frekuensi (Orang) & Persentase (\%) \\
\hline $0.5-1$ & 13 & 21.7 & 12 & 20 \\
\hline $1.5-2$ & 13 & 21.7 & 13 & 21.7 \\
\hline $2.5-3$ & 2 & 3.3 & 5 & 8.3 \\
\hline$>3$ & 0 & 0 & 2 & 3.3 \\
\hline Jumlah & 28 & 45.4 & 32 & 54.6 \\
\hline
\end{tabular}

Jumlah tanggungan merupakan salah satu faktor yang perlu diperhatikan dalam menentukan pendapatan dan memenuhi kebutuhan suatu rumah tangga (Hasyim, 2003) .Banyaknya jumlah tanggungan keluarga akan mendorong petani untuk melakukan banyak aktivitas terutama dalam mencari dan menambah pendapatan keluarganya. Semakin banyak anggota keluarga akan semakin besar pula beban hidup yang akan ditanggung atau harus dipenuhi. Jumlah tanggungan keluarga yang dimaksud dalam penelitian ini adalah jumlah anggota keluarga yang masih menjadi tanggungan keluarga petani responden. Sebagian besar petani responden di daerah penelitian memiliki tanggungan keluarga sebanyak 1 sampai 2 orang. Petani yang tidak memiliki tanggungan tidak ada yang memasarkan bokarnya ke pedagang pengumpul desa, sedangkan petani dengan tanggungan lebih dari 4 orang lebih memilih memasarkan bokar ke pedagang pengumpul desa. Lebih jelasnya mengenai jumlah tanggungan keluarga petani responden dapat dilihat pada Tabel 5.

Tabel 5. Distribusi Petani Responden Berdasarkan Jumlah Tanggungan di Daerah Penelitian Tahun 2015

\begin{tabular}{|c|c|c|c|c|}
\hline \multirow{2}{*}{ Luas Lahan (Hektar) } & \multicolumn{2}{|c|}{$\begin{array}{c}\text { Memasarkan ke } \\
\text { Koperasi/Kelompok Tani }\end{array}$} & \multicolumn{2}{|c|}{$\begin{array}{c}\text { Memasarkan ke } \\
\text { Pedagang Pengumpul Desa }\end{array}$} \\
\hline & $\begin{array}{c}\text { Frekuensi } \\
\text { (Orang) }\end{array}$ & Persentase (\%) & Frekuensi (Orang) & Persentase (\%) \\
\hline Tidak Ada Tanggungan & 3 & 5 & 0 & 0 \\
\hline $1-2$ & 23 & 38.3 & 22 & 36.7 \\
\hline $3-4$ & 2 & 3.3 & 9 & 15 \\
\hline$>4$ & 0 & 0 & 1 & 1.7 \\
\hline Jumlah & 28 & 46.6 & 32 & 53.4 \\
\hline
\end{tabular}

Tabungan merupakan sebagian dari pendapatan yang tidak dibelanjakan atau digunakan. Tabungan ini penting untuk dimiliki oleh seseorang termasuk petani karet sebagai metode untuk menghemat pengeluaran sehingga mendapatkan simpanan baik dalam bentuk dana maupun barang yang dapat digunakan sewaktu-waktu bila dibutuhkan. Tabungan dalam penelitian ini meliputi uang, hewan ternak besar seperti kerbau, sapi, kambing dan barang-barang seperti emas serta barangbarang lainnya yang dapat dijadikan sebagai aset sehingga bisa dijadikan sebagai cadangan untuk memenuhi kebutuhan mendesak sewaktu-waktu. Petani responden di daerah penelitian sebagian besar memiliki tabungan dengan jumlah Rp 8.000.000,- sampai Rp 15.000.000,- dengan persentase 
sebesar 75 persen. Petani responden yang memiliki tabungan lebih dari Rp 23.000.000,- memiliki frekuensi 1 orang dan lebih memilih pedagang pengumpul desa sebagai lembaga pemasaran bokarnya. Jumlah tabungan yang dimiliki petani responden lebih jelasnya dapat dilihat pada Tabel 6 .

Tabel6. Distribusi Petani Responden Berdasarkan Jumlah Tabungan di Daerah Penelitian Tahun 2015

\begin{tabular}{ccccc}
\hline & \multicolumn{2}{c}{$\begin{array}{c}\text { Memasarkan ke } \\
\text { Jumlah Tabungan (Rupiah) }\end{array}$} & \multicolumn{2}{c}{$\begin{array}{c}\text { Memasarkan ke } \\
\text { Pedagang Pengumpul Desa }\end{array}$} \\
\cline { 2 - 5 } & $\begin{array}{c}\text { Frekuensi/Kelompok Tani } \\
\text { (Orang) }\end{array}$ & Persentase (\%) & Frekuensi (Orang) & Persentase (\%) \\
\hline $8.000 .000-15.000 .000$ & 23 & 38.3 & 22 & 36.7 \\
$16.000 .000-23.000 .000$ & 2 & 3.3 & 9 & 15 \\
$\geq 23.000 .000$ & 0 & 0 & 1 & 1.7 \\
Jumlah & 28 & 46.6 & 32 & 53.4 \\
\hline
\end{tabular}

Produksi pertanian dapat dikatakan sebagai suatu usaha pemeliharaan dan penumbuhan komoditi pertanian untuk memenuhi kebutuhan manusia. Pada proses produksi pertanian terkandung pengertian bahwa guna atau manfaat suatu barang dapat diperbesar melalui suatu penciptaan guna bentuk yaitu dengan menumbuhkan bibit sampai besar dan pemeliharaan. Produksi yang dimaksud dalam penelitian ini adalah hasil karet yang dihasilkan oleh petani dalam waktu satu bulan. Sebagian besar petani di daerah penelitian memiliki produksi dengan jumlah kurang dari 200 $\mathrm{kg} / \mathrm{bulan}$. Selain itu, petani responden dengan jumlah produksi lebih dari $400 \mathrm{~kg} / \mathrm{bulan}$ lebih memilih pedagang pengumpul desa sebagai lembaga pemasaran bokarnya. Lebih jelasnya mengenai produksi karet di daerah penelitian dapat dilihat pada Tabel 7.

Tabel 7. Distribusi Petani Responden Berdasarkan Produksi di Daerah Penelitian Tahun 2015

\begin{tabular}{ccccc}
\hline \multirow{2}{*}{ Produksi (Kg/Bulan) } & \multicolumn{2}{c}{$\begin{array}{c}\text { Memasarkan ke } \\
\text { Koperasi/Kelompok Tani }\end{array}$} & \multicolumn{2}{c}{$\begin{array}{c}\text { Memasarkan ke } \\
\text { Pedagang Pengumpul Desa }\end{array}$} \\
\cline { 2 - 5 } & $\begin{array}{c}\text { Frekuensi } \\
\text { (Orang) }\end{array}$ & Persentase (\%) & Frekuensi (Orang) & Persentase (\%) \\
\hline$\leq 90$ & 4 & 6.7 & 5 & 8.3 \\
$100-190$ & 10 & 16.7 & 19 & 31.7 \\
$200-290$ & 11 & 18.3 & 6 & 10 \\
$300-390$ & 3 & 5 & 0 & 0 \\
$\geq 400$ & 0 & 0 & 2 & 3.3 \\
Jumlah & 28 & 46.7 & 32 & 53.3 \\
\hline
\end{tabular}

\section{Uji Ekonometrika}

Uji multikolinearitas bertujuan untuk menguji apakah model pada model regresi ditemukan adanya korelasi diantara variabel independen. Dalam penelitian ini untuk melihat terjadi atau tidak terjadinya kasus multikolinearitas dilihat dari nilai matriks korelasi (correlation matrix) pada output hasil analisis. Menurut Ghozali (2001), jika antar variabel bebas memiliki korelasi yang cukup tinggi (diatas 0,90$)$ maka hal ini merupakan indikasi adanya multikolinearitas. Nilai korelasi antar variabel independen dalam penelitian ini semuanya kurang dari 0,90 (Lampiran 11) sehingga dapat disimpulkam bahwa model regresi dalam penelitian ini tidak terjadi multikolinearitas atau tidak ada korelasi antar masing-masing variabel independennya.

Uji heteroskedastisitas digunakan untuk menguji apakah dalam model regresi terjadi ketidaksamaan variansi dari residual satu pengamatan ke pengamatan yang lain. Regresi binary logistic merupakan salah satu alternatif model probabilitas linear yang memiliki variansi error yang 
tidak berdistribusi normal, hal ini berarti terjadi pelanggaran terhadap asumsi klasik. Hal ini ditunjukkan pada tabel hasil analisis dengan nilai error berada antara 0,000 - 0,546 (Lampiran 11). Nilai dari variansi error ini menunjukkan terjadinya kasus heteroskedastisitas.

Menurut Setiawan (2010) terdapat beberapa cara untuk mengatasi kasus heteroskedastisitas, salah satunya yang digunakan dalam penelitian ini adalah dengan transformasi variabel yang disebut logit transformer yakni dengan menentukan logaritma natural (In) dari persamaan probabilitas sehingga model persamaan regresi binary logistic dalam penelitian ini adalah sebagai berikut :

$$
\hat{Y}=\beta_{0}+\beta_{1} X_{1}+\beta_{2} X_{2}-\beta_{3} X_{3}+\beta_{4} X_{4}+\beta_{5} X_{5}
$$

$\hat{Y}$ merupakan log rasio peluang pengambilan keputusan memasarkan bahan olah karet yang tidak hanya linear dalam $X$ tetapi juga (dari sudut pandang estimasi) linear dalam parameter $\hat{Y}$.

\section{Faktor-Faktor yang Mempengaruhi Keputusan Petani dalam Memasarkan Bahan Olah Karet}

Hasil regresi binary logistic pada faktor-faktor yang mempengaruhi keputusan petani dalam memasarkan bahan olah karet sebagai berikut :

Tabel 8. Analisis Regresi Binary Logistic Pada Faktor-Faktor yang Mempengaruhi Pengambilan Keputusan Petani dalam Memasarkan Bahan Olah Karet di Daerah Penelitian Tahun 2015

\begin{tabular}{|lccc|}
\hline Variabel & Koefisien $(\beta)$ & Sig $(\mathrm{p}$-value $)$ & Exp $(\mathrm{B})$ \\
\hline Pendidikan Petani $\left(X_{1}\right)$ & 0,249 & 0,073 & 1,283 \\
Pengalaman Petani $\left(X_{2}\right)$ & 0,024 & 0,557 & 1,024 \\
Jumlah Tanggungan $\left(X_{3}\right)$ & $-1,653$ & 0,002 & 0,191 \\
Tabungan $\left(X_{4}\right)$ & 0,000 & 0,003 & 1,000 \\
Produksi $\left(X_{5}\right)$ &,- 036 & 0,004 & 0,965 \\
Constant & $-2,063$ & 0,389 & 0,127 \\
\hline Hosmer and Lemeshow test $=0,626$ & & & \\
Nagelkerke $R$ Square $\left(\mathrm{R}^{2}\right) \quad=0,702$ & & & \\
\hline
\end{tabular}

Uji Hosmer and Lemeshow digunakan untuk mengetahui pengaruh variabel-variabel independen (pendidikan, pengalaman, jumlah tanggungan, tabungan dan produksi) secara bersamasama terhadap keputusan memasarkan ke lembaga pemasaran bahan olah karet dalam model yang digunakan. Hasil analisis menunjukkan bahwa nilai p-value pada tabel Hosmer and Lemeshow sebesar 0,626 (lebih besar dari $\alpha=0,05$ ). Hal ini berarti $\mathrm{H}_{0}$ diterima dan diambil keputusan bahwa model yang digunakan dalam penelitian ini telah cukup mampu menjelaskan data (sesuai).

Uji Goodness of Fit digunakan untuk mengukur tingkat keberhasilan dalam memprediksi nilai variabel dependen atau mengetahui kecocokan dalam model regresi yang digunakan. Koefisien $\left(R^{2}\right)$ digunakan untuk mengukur seberapa besar variasi dari variabel dependennya dapat dijelaskan oleh variabel-variabel independennya. Hasil analisis menunjukkan bahwa nilai Nagelkerker $R$ Square adalah sebesar 0,702. Hal ini menunjukkan bahwa sebanyak 70,2 persen variasi atau keragaman dari variabel dependennya (keputusan) dapat dijelaskan oleh model, sedangkan sisanya yaitu sebesar 29,80 persen dijelaskan oleh variabel lain diluar model.

Nilai overall percentage yang diperoleh pada classification table menjelaskan klasifikasi dalam penafsiran nilai variabel dependen. Nilai overall percentage sebesar 85,0 persen yang berarti model regresi ini dapat memprediksi keputusan memasarkan bahan olah karet seorang petani sebesar 85,0 persen. 


\section{Jumlah Tanggungan}

Jumlah tanggungan memiliki $p$-value sebesar $0,002<\alpha(0,05)$ dengan koefisien yang negatif. $\mathrm{Hal}$ ini berarti jumlah tanggungan berpengaruh signifikan secara negatif terhadap keputusan petani memilih untuk memasarkan bahan olah karet ke koperasi/kelompok tani. Semakin banyak jumlah tanggungan, petani akan cenderung untuk memilih memasarkan bahan olah karet ke pedagang pengumpul desa. Nilai odds ratio sebesar 0,191 berarti setiap adanya penambahan tanggungan sebanyak 1 orang, maka peluang petani untuk menerapkan keputusan memasarkan bahan olah karet ke koperasi/kelompok tani 0,191 kali dari sebelum terjadinya penambahan tanggungan.

$\mathrm{Hal}$ ini sejalan dengan penelitian yang dilakukan oleh Miske Roihani (2000) yang menunjukkan bahwa jumlah tanggungan keluarga berpengaruh secara signifikan terhadap keputusan petani dalam pemilihan bentuk produksi dan analisis ekonomi rumah tangga petani tembakau. Variabel jumlah tanggungan keluarga memiliki nilai p-value sebesar 0,151 pada taraf signifikansi 20 persen. Petani dengan jumlah anggota keluarga yang banyak cenderung memilih untuk memproduksi tembakau basah dikarenakan biaya untuk memproduksi tembakau rajangan membutuhkan biaya yang tidak sedikit dan petani akan menggunakan uangnya untuk memenuhi kebutuhan hidup keluarganya.

Petani di daerah penelitian yang memiliki jumlah tanggungan keluarga yang banyak lebih memilih memasarkan bahan olah karetnya ke pedagang pengumpul desa ada kaitannya dengan biaya pemenuhan kebutuhan hidup yang tidak sedikit. Petani dengan tanggungan keluarga yang banyak memerlukan biaya hidup yang bisa diperoleh dalam waktu yang singkat. Hal ini bisa didapat dengan memasarkan bahan olah karet ke pedagang pengumpul desa dengan waktu pemasaran yang kondisional serta proses peminjaman dana yang mudah.

\section{Tabungan}

Tabungan memiliki p-value sebesar $0,003<\alpha(0,05)$ dengan koefisien yang positif. Hal ini berarti tabungan berpengaruh signifikan terhadap keputusan petani memilih untuk memasarkan bahan olah karet ke koperasi/kelompok tani. Semakin bertambahnya jumlah tabungan, peluang petani memilih memasarkan bahan olah karet ke koperasi akan meningkat. Nilai odds ratio sebesar 1,000 berarti setiap terjadi pertambahan jumlah tabungan sebesar $\mathrm{Rp} 1$ maka peluang petani menerapkan keputusan memasarkan bahan olah karet ke koperasi/kelompok tani sama dengan sebelum terjadinya penambahan jumlah tabungan.

Tabungan merupakan bagian pendapatan yang tidak dikonsumsi, maka semakin tinggi pendapatan seorang petani semakin tinggi pula tingkat tabungannya. Kelebihan dari pendapatan yang tidak dibelanjakan untuk dikonsumsi dapat disisihkan untuk tabungan. Selain berhubungan dengan tingkat pendapatan yang diperoleh rumah tangga petani, tabungan juga memiliki hubungan dengan konsumsi. Konsumsi merupakan suatu hal yang mutlak dilakukan dan dibutuhkan oleh seseorang, begitu juga dengan seorang petani dalam memenuhi kebutuhan hidup sehari-hari. Pemenuhan kebutuhan sehari-hari dalam bentuk konsumsi membutuhkan biaya yang diperoleh dari pendapatan. Apabila tingkat konsumsi rendah, maka peluang untuk menabung semakin tinggi diakibatkan sisa dari pendapatan.

Tabungan dalam rumah tangga petani bermanfaat sebagai sarana untuk memenuhi kebutuhan yang mendesak sehingga tidak perlu untuk mencari pinjaman baik dalam bentuk uang atau barang/jasa kepada pihak lain. Petani yang memiliki tabungan di daerah penelitian tidak ada yang mempunyai hutang dengan pedagang pengumpul desa dikarenakan mereka memiliki cadangan dana untuk keperluan yang mendesak. Tabungan selain dalam bentuk uang, di daerah penelitian juga diinvestasikan oleh petani dalam bentuk barang seperti emas, kendaraan serta hewan ternak yaitu sapi dan kambing sehingga memperkecil peluang memiliki hubungan dengan pedagang pengumpul desa khususnya dalam hal peminjaman dana. 


\section{Produksi}

Produksi memiliki p-value sebesar $0,004<\alpha(0,05)$ dengan koefisien yang negatif. Hal ini berarti produksi berpengaruh signifikan secara negatif terhadap keputusan petani memilih untuk memasarkan bahan olah karet ke koperasi/kelompok tani. Semakin meningkatnya produksi, petani akan cenderung untuk memilih memasarkan bahan olah karet ke pedagang pengumpul desa. Nilai odds ratio sebesar 0,965 berarti setiap adanya peningkatan produksi sebesar $1 \mathrm{~kg}$, maka peluang petani untuk menerapkan keputusan memasarkan bahan olah karet ke koperasi/kelompok tani 0,965 kali dari sebelum terjadinya peningkatan produksi.

Penelitian oleh Ratna Komala Dewi dan Sudiartini (1999) mengenai faktor sosial ekonomi yang mempengaruhi pengambilan keputusan petani dalam sistem penjualan sayuran di Desa Candikuning Bali. Hasil penelitiannya menunjukkan bahwa penerimaan petani memiliki keterkaitan langsung dengan keputusan petani untuk tidak menebaskan sayurannya (transaksi jual beli sebelum panen). Variabel penerimaan memiliki koefisien regresi sebesar 0,001218 yang signifikan pada $\alpha$ sebesar lima persen. Semakin besar penerimaannya, maka petani memutuskan untuk tidak menebaskan sayurannya. Penerimaan besar yang diterima petani sudah cukup untuk mencukupi kebutuhan sehari-hari sehingga mereka tidak perlu menebaskan sayurannya. Produksi dalam hubungannya dengan keputusan petani dalam memasarkan bokarnya, selain berkorelasi dengan penerimaan juga berkorelasi dengan harga. Harga yang tinggi didukung dengan jumlah produksi maksimal menyebabkan petani memperoleh penerimaan yang tinggi pula.

Petani di daerah penelitian sebagian besar sudah mengetahui tentang informasi harga bahan olah karet yang berlaku baik di koperasi/kelompok tani maupun di pedagang pengumpul desa. Petani tidak hanya sebatas mengetahui berapa harganya, akan tetapi pengetahuan petani sudah pada sampai tahap menganalisis. Hasil analisis menunjukkan bahwa petani yang memiliki jumlah produksi yang tinggi memilih pedagang pengumpul desa sebagai lembaga tempat memasarkan bokarnya. Hal ini dikarenakan dengan selisih harga yang sedikit ( $\mathrm{Rp} 500,-$ ) antara pedagang pengumpul desa dengan koperasi/kelompok tani pada saat penelitian dilaksanakan. Selain itu, kemudahan dalam proses pemasaran bahan olah karet pada pedagang pengumpul desa juga menjadi pertimbangan petani seperti perolehan insentif (biaya transportasi) untuk petani yang mengantar langsung ke rumah pedagang sebagai tempat pemasaran bahan olah karet.

\section{KESIMPULAN}

Berdasarkan hasil penelitian terhadap keputusan petani dalam memasarkan bahan olah karet dapat disimpulkan bahwa keputusan petani untuk memilih memasarkan bahan olah karetnya ke lembaga pemasaran yaitu ke koperasi/kelompok tani atau ke pedagang pengumpul desa dipengaruhi secara signifikan oleh 3 faktor. Faktor-faktor tersebut antara lain diantaranya jumlah tanggungan, tabungan dan produksi. Selain faktor-faktor tersebut, keputusan petani memilih lembaga pemasaran bahan olah karet juga didukung oleh faktor kemudahan dalam proses pemasaran.

\section{UCAPAN TERIMA KASIH}

Pada kesempatan kali ini penulis menyampaikan ucapan terima kasih kepada kepada Kepala Desa Pondok Meja, Pengurus Koperasi Usaha Jaya dan Pengurus Kelompok Tani yang memfasilitasi pelaksanaan penelitian di lapangan.

\section{DAFTAR PUSTAKA}

BPS Provinsi Jambi. 2013. PDRB Provinsi Jambi Menurut Lapangan Usaha Tahun 2009 - 2013. BadanPusat Statistik Provinsi Jambi, Jambi. 
Disbun Provinsi Jambi. 2013. Laporan Tahunan Disbun Provinsi Jambi, Jambi.

Gujarati DN. 2006. Dasar-Dasar Ekonometrika. Erlangga, Jakarta.

Hasan I. 2002. Pokok-Pokok Materi Teori Keputusan. Ghalia Indonesia, Jakarta.

Hasyim Hasman. 2003. Analisis Hubungan Faktor Sosial Ekonomi terhadap Penyuluhan Pertanian. Laporan Hasil Penelitian. Universitas Sumatera Utara, Medan.

Ihsan Fuad. 2005. Dasar-Dasar Kependidikan. PT Rineka Cipta, Jakarta.

Miske Roihani. 2000. Faktor yang Mempengaruhi Keputusan Petani dalam Pemilihan Bentuk Produksi dan Analisis Ekonomi Rumah Tangga Petani Tembakau Studi Kasus Petani Tembakau Kabupaten Temanggung. Skripsi. IPB, Bogor.

Ratna Komala Dewi dan Sudiartini. 1999. Faktor Sosial Ekonomi yang Mempengaruhi Pengambilan Keputusan Petani dalam Sistem Penjualan Sayuran di Desa Candikuning. Jurnal Penelitian. Universitas Udayana, Bali.

Suratiah Ken. 2006. Ilmu Usahatani. Penebar Swadaya, Jakarta.

Trihendardi Cornelius. 2007. Kupas Tuntas Analisis Regresi, Strategi Jitu Melakukan Analisis Hubungan Causal. Penerbit Andi, Yogyakarta. 